\title{
STORYTELLING IN TEACHING LITERACY: BENEFITS AND CHALLENGES
}

\author{
Intan Satriani \\ English Education Department, Faculty of Language Education, IKIP Siliwangi, Indonesia \\ E-mail: intan.satriani@yahoo.co.id
}

APA Citation: Satriani, I. (2019). Storytelling in teaching literacy: Benefits and challenges. English Review: Journal of English Education, 8(1), 113-120. doi: 10.25134/erjee.v8i1.1924.

Published: 01-12-2019

\begin{abstract}
Literacy has become a crucial position in education, especially in Indonesia. It is used as one of ways to develop education through developing the culture of reading, writing, and counting. The study aims to find out benefits and challenges of implementing storytelling in teaching literacy. The study employed a qualitative descriptive research design. The data were obtained from students' interview and observation. The findings found some benefits in implementing teaching program which include using two languages as the medium of interaction, providing suitable learning materials and various media, using of dramatization to show a character's expression, asking moral value of the story as an evaluation instrument, developing students' literacy ability, arousing students' imagination, enriching students' vocabulary, and developing students' reading awareness and interest. Meanwhile, some challenges found in implementing teaching program are students' proficiency and length of texts. Based on those findings, it is suggested to provide more times to truly explore students' literacy ability and their preference in story.
\end{abstract}

Keywords: storytelling; teaching literacy; benefits; challenges; EFL classroom.

\section{INTRODUCTION}

Storytelling is an activity to pass the information from person to person and from one generation to the next generation (McDrury \& Alterio, 2003). Storytelling is simple and practical because stories, which are used as the media, are easily obtained (Wajnryb, 2003). Hence, the use of storytelling as a teaching tool has been conducted in the areas of teacher education, higher education, early childhood education, and nursing education.

Storytelling shows some benefits, especially storytelling as a pedagogical tool. It can motivate students (Wright, 2008), help children in memorizing words learned (Arietawati, 2011), improve their vocabulary mastery (Widiastika, 2011), encourage children to learn English (Slattery \& Willis, 2001), increase their moral value (Rusdi, 2006), provide inexpensive media in teaching rich language experience (Wright, 2008), and enhance students' interest in reading (Slattery \& Willis, 2001). Moreover, storytelling is categorized as one of teaching techniques that enable Asian EFL students in elementary and secondary school to enjoy reading and writing (Paul, 2003) and to build students' interest in literacy and learning English. It means that storytelling can be an alternative way to enhance student's literacy in an EFL classroom. Not only in EFL setting, storytelling is also substantial in ESL setting. Storytelling is able to stimulate ESL students to be more enthusiastic during learning process in England (McClelland, n.d in Hana, 2011).

Furthermore, storytelling is important to improve students' listening and writing skills (McGrath, 2000). It means that storytelling is a part of literacy practice that may influence students' language proficiency. Literacy practice has some important characteristics, such as to develop language and brain, to practice logical and critical thinking (Metcalfe et al., 2013), and to apply value or moral (Taylor, 2000).

Relating to EFL context, English should be a medium to develop students' literacy in Indonesia. Thus, it is essential for EFL educators to reconceptualize the teaching of English in order to bring the betterment and improvement of students' literacy in Indonesia. One alternative way to increase literacy in Indonesia is through the use of storytelling in the classroom. Basically, there are several benefits that can be gained by secondary students and teachers through storytelling in teaching literacy, including reading and writing. The benefits and challenges are described as follow.

Incorporating to the benefits of storytelling, firstly, through storytelling teacher can enhance students' interest in reading (Slattery \& Willis, 2001) and make students enjoy learning language (Rusdi, 2006; MacKinney, 1996 in Al-Mansour \& Al-Shorman, 2011). Moreover, it also motivates 
students to read and improve their reading comprehension (Scott \& Ytreberg, 1990). Besides, storytelling can also be used to prepare students to write their own stories (Scott \& Ytreberg, 1990). The example of students' writing development through storytelling can be seen from students' writing journal. In that activity, teacher does not only obtain the data of students' writing, but also their development of analytical and reasoning skills. In this case, storytelling can develop students' writing ability as it provides opportunities to discover some important dialogue and to understand stories and story elements (Campbell \& Husek, 2009).

In line with literacy, storytelling promotes expressive and receptive language development, namely written composition and reading comprehension (Peck, 1989). Second language learners who share personal experiences through storytelling are able to demonstrate linguistic growth. The text of the story also provides the potential for comprehensible input. This input can be achieved in multi ways, for instance individual reading, a number of group sharing, groups of students working on a core text and taking it in different directions according to their own imaginations (Wajnryb, 2003). In increasing students' novels word comprehension, vocabulary eliciting questions and noneliciting questions also can be used in storytelling activity (Walsh \& Blewitt, 2006).

Students' interest in reading story can be enhanced when students have heard a story once. Teacher can tell the students that each time they read a book, they will become more familiar with the language of the story and will be able to participate more in different ways (Slattery \& Willis, 2001). The way teachers observe reading behavior is linked to different reader purposes which are linked to situational context and also to social expectations, for example what kind of reading behavior is expected in classrooms, families, or particular religious' settings (Wallace, 1992).

Secondly, storytelling using local legends can help teacher to set values and to introduce cultural identities to the students (Pahl \& Rowsell, 2005). There are different kinds of literacy practices within communities, through cultural, social and educational experiences, such as read story books as children, read to our children as parents, communicate with distant friends or relatives through reading (Hood, Solomon, \& Burns, 2005).
Third, learning literacy through storytelling can help students to get sense or meaning of text (Metcalfe, et al., 2013). Understanding meaning of text has a relation with the comprehension of vocabulary and grammar. In using storytelling to teach reading and writing, it can help learners to use vocabulary and grammar correctly. Learning to tell and write effective stories is an effective language learning application for students to increase their knowledge of vocabulary and grammar (Nicholas, Rossiter, \& Abbott, 2011).

Fourth, storytelling allows students to increase their imagination (Wright, 2008). In case of picture books, the narrative nature of picture books invites readers or viewers to see how artistic elements act as a form of visual communication. Through illustration, illustrator shows the relationship a character has with other characters or further extends a character's intentions in the plot through movement, performance and gesture (Pahl \& Rowsell, 2005). Needlman (2004 in Al-Mansour \& Al-Shorman, 2011) adds that reading aloud through storytelling can build students' imagination.

Thus, although there are various research on storytelling in teaching literacy, there is still lack of studies investigating the benefits and challenges of implementing storytelling in teaching literacy. Addressing this gap, this study focuses on obtaining perception from students' point of view about teaching literacy through storytelling.

\section{METHOD}

This present study employed a qualitative descriptive method. This method is used to examine questions that can best be answered by verbally describing how participants in a study perceive and interpret various aspect of their environment (Crowl, 1996). Qualitative research provides opportunities for researchers to study social phenomena in relation to people's everyday lives. Through a process of data interpretation, qualitative research provides information about what, why and how a phenomenon in a society happens. This is in line with what Denzin and Lincoln (2005) say that qualitative research also involves an interpretive, naturalistic approach to the world. In addition, Yin (1994) also elaborates that employing qualitative method provides researchers with opportunities to represent the views and perspectives of the people/participants in a study. 
The study was undertaken at a private Junior High School in Cipatat, rural part of West Bandung, West Java province, Indonesia. The school is a suburban school with a student enrolment drawn predominantly from disadvantaged families which had lower motivation in continuing their study to senior high school. Most of them are prefer to work after they graduated from their junior high school.

The participants of this study consisted of six eighth grader of junior high school. They were selected as the representative of a group which is appropriate with one of case study features (Cohen, Manion, \& Morrison, 2007). The six students were divided into three categories, namely two students from high level achievement, two from middle level achievement, and two from lower level achievement based on their performance in previous reading lesson and diagnostic writing. All participants were all Sundanese who have Bahasa Sunda as their mother tongue. Bahasa Indonesia is their second language. English and Arabic are thus their foreign language.

Upon the chosen steps of an observation classroom, this study conducted a preliminary observation to the classroom and made a consultation with the prior English teacher (it was taken one term). Students attended individual interview which run about 15 minutes and was audio taped. This interview attempted to find out students' perceptions about the implementation of storytelling (the strengths, weaknesses, and what students think they have obtained in their classroom). Prior to the interview, the researcher informed the participants that the interview was audiotaped and their names was not mentioned to keep their identity confidential.

\section{RESULTS AND DISCUSSION}

This section delineates the depiction of research findings of the study and the discussion dealing with the data investigated and collected from the observation and interview. The presentation of this section is divided into two sections. The first section discusses the benefits of the implementation of storytelling technique in developing students' literacy skill and the second section elaborates the challenges of implementing the technique in teaching literacy to the students. The discussion of this teaching program is incorporated with the instruments used and theory to support the study.

\section{Benefits of implementing storytelling in teaching literacy}

This study found eight benefits of implementing storytelling in teaching literacy. The benefits cover using two languages as the medium of interaction, the provision of suitable learning materials and various media, using dramatization to show a character's expression, asking moral value of the story as an evaluation instrument, developing students' literacy skills, arousing students' imagination, helping students to share their experiences, improving students' vocabulary mastery, and increasing students' reading awareness and interest. The aforementioned benefits are described below.

\section{Using two languages as the medium of interaction}

Before implementing storytelling activities, the researcher informed the students about the teaching program. This activity was intended to realize that what is to be learnt should be made clear to the students (Feez, 2002). The medium of interaction at all stages throughout the teaching program was English and Bahasa Indonesia. The two languages were used during the implementation of the program because of some reasons. First, Bahasa Indonesia was used especially when the students or the teacher found difficulty in expressing their ideas, explaining the meaning, or discussing the main ideas in reading and writing in English (see Willis, 1981 cited in Emilia, 2010). Second, bilingualism was expected to affect positively both students' intellectual and linguistic progress and allow for their greater sensitivity to linguistic meanings and more flexibility in their thinking (Cummins, 1996 cited in Emilia, 2005). Meanwhile, the use of Bahasa Indonesia was expected to avoid the silence of the class so the students could participate actively in the teaching program (Emilia, 2005).

\section{The provision of suitable learning materials and various media}

The selection of suitable materials was considered important in the teaching program especially the implementation of storytelling. With regard to the learning materials, this study focused on two main materials, namely narrative text and the stories itself. Firstly, related to narrative text. Due to narrative text is the focus of storytelling, teacher should make students aware about the content of the text. Students were firstly introduced to the description of narrative text which include the definition of narrative text, the social function of narrative text, the schematic structure of narrative text, the language features 
of narrative text, and the example of narrative text.

In addition, another component in learning material is stories for students. Those stories were selected based on the characteristics of the best or interesting stories for children. Derewianka (1990) states that to introduce the author who would be sure to grab students' interest can be one of ways to make students love of books and enthusiasm for good children's literature. The selection of the stories based on several points; 1) students' familiarity with the story; 2) the colored picture series of the stories; and 3) teacher's performance skills in telling the stories. Rahmawati (2014) suggested that it will be better if the story is the local one with good values.

\section{Using dramatization to show a character's expression}

The observation data showed that the students enjoyed the story started from the beginning until the end of the story. It was because the teacher used interesting media and explained the story expressively. By showing and telling the story expressively, they seemed more motivated to know the content of the story. In this activity, the teacher also used some dramatization to show a character's expression or emotion. According to Scott and Ytreberg (1990), character's expression or gesture can attract students' interest in comprehending the story. During telling the story, the teacher located the storybook in the location that was visible by the children and moved around so that everyone could see. It can be seen through students' expression below that they could respond to the story.

$\mathrm{T}$ : "Look at the picture! Can the horse catch the gingerbread man?"

S\#3 : "No, Ibu. Gingerbread man run from horse."

Then, in the process of storytelling, the teacher invited the class to visualize the vocabulary and to understand the basic vocabulary by using TPR (total physical response). The students responded the vocabularies in a physical way by carrying out the instructions, for example "he did some gardening and fishing in his daily life." In addition, in facilitating good visualization of the story, the teacher displayed a huge picture in front of the classroom. After that, she put up the pictures of the characters on the board.

\section{Asking moral value of the story as an evaluation instrument}

At the end of the second unit, the students were asked to think of the moral value of the story. One student said that the moral value of the story was "we have to be honor to our mother." The other said that "we must love our family like sarah, percy and bill." Fable is s proper example of fictitious story that teach moral lesson (Sherman, 2008).

The instrument of the evaluation used was cloze procedure. This test was chosen as test instrument in this research because it can support students' understanding of grammar, spelling, and sentence construction (Hancock \& Leaver, 2006). In line with the data, the result presented that through ten questions given to the students, students showed their development. In the first section, their vocabulary was developed. All students were able to put some proper words into the provided boxes. Furthermore, in the second section, they knew what they should do, because it was the second time for them to meet that type of questions. Since they are interested in the story, they easily found the correct partner of the blank sentences.

\section{Developing students' literacy skill}

Based on the data of students' interview, it was found that students developed their literacy capacity and skill. The development of students' literacy skill can be seen in the following excerpt:

I understand the story, because when teacher tells the story, she gives me a text of the story so that we can understand the plot of that story. (S5) (Interview, translated version)

The above excerpt also showed that through storytelling, students can explore their writing ability. McDrury and Alterio (2003) support the data that through storytelling in the field of education and teaching learning, learners can be encouraged to tell stories by their own words using their complex ideas, concepts or information which they had obtained before.

Besides, the selection of the story is important in implementing storytelling in the classroom. As stated by Wright (2008), through the closest story from students, it can be the best activities for them in obtaining the gist of the story. The statement relates with students' perception below.

\footnotetext{
I like The Ginger Bread man's story. (S5) (Interview, translated version)

The story is easy to be understood. I understand with the story, because there are some interesting pictures in the book. (S3) (Interview, translated version)
}

Students \#1 and Student \#4 understand the story because they have good first impression toward the story. Furthermore, they also have 
ENGLISH REVIEW: Journal of English Education

Volume 8, Issue 1, December 2019
p-ISSN 2301-7554, e-ISSN 2541-3643

https://journal.uniku.ac.id/index.php/ERJEE prior knowledge of the story given. Related to the literacy, in implementation, students do not only feel interesting and enjoyable with the story, but also their thinking skills can be developed (Slattery \& Willis, 2001, p. 96).

I like the part when we read using big book, because the picture is clear and big. (S5) (Interview, translated version)

In addition to the story itself, in developing students' literacy skill, the media of telling story also should be noticed. The use of visual tools are also important as one of supporting media that supports storytelling activities (Sprenger, 2010, p.101).

\section{Arousing students' imagination}

Students in junior high school (from 13-14 years old) tend to enjoy some variation of story, such as complex story, adventure story, and romantic story (Phillips, Burwood \& Dunford, 1999; Pinter, 2006; Wright, 2008; Hana, 2011). Students need pictures, expressions, and visual tools in exploring story. Visual tools are able to facilitate learners in understanding the meaning of the story. Those can also dig students' imagination, as supported by students' perception below.

Because telling the story using gesture and expression, the story is easy to be comprehended. This is the first time for me to know the story. First, I do not understand the meaning of the story in English. However, because teacher tells the story using body movements and pictures, I can imagine the story. (S1) (Interview, translated version)

I like Babies Owl story, mam. The story is funny. The picture is big. Then, I can see big font size. The most important, I like animal story. (S2) (Interview, translated version)

Based on the result of students interview, Tooze (1959) supports that stories can inspire students in developing their imagination. The selection of fable also influences students in arousing their imagination. It means that students from elementary up to secondary level put their huge attention to the animals characters (Pinter, 2006) or fictitious story.

\section{Improving students' vocabulary mastery}

In teaching vocabulary to secondary students, teachers do not only use one technique or method, but they can also apply storytelling as the main technique in increasing students' vocabulary mastery. Stories can be utilized as good sources of learning vocabulary and structure (Pinter,
2006, p.122). The previous theory is supported by result of student's interview below.

Before I learn using storytelling, I did not know what the meaning of that story is. Through this activity, I feel my vocabulary increased. (S1) (Interview, translated version)

The activity of telling stories can add my vocabulary, because teacher tells different kind of stories. (S1) (Interview, translated version)

Related to student one's perception, she felt that her vocabulary was increased through learning using storytelling. In the activities of storytelling, teacher does not only focus on the story itself, but also he or she can focus on the specific lesson, for example building students' vocabularies (Zaro \& Salaberri, 1995, p. 9).

Increasing students' reading awareness and interest

Reading is a part of daily life for people who live in literate communities that much of the time they hardly consider either the purposes or process involved (Wallace, 1992, p. 5). Because of reading is the primary to any definition of literacy before writing, it is important for teacher to assist students to be interested in reading comprehension.

Learning using storytelling make me want to learn more and to try reading and writing in English. I am more interesting in learning English. (S1) (Interview, translated version)

Incorporating with the student's interview result, learning reading and writing through storytelling made student's engagement in learning increased. It is supported by Scott and Ytreberg (1990, p.69; Hana, 2011, pp.15-16) who state in teaching storytelling, teacher can integrate both reading and writing. That is because reading and writing is the example of learning consolidation.

Telling stories using expression and using interesting book to be read make me enjoy and understand the story. (S3) (Interview, translated version)

\section{Challenges of implementing storytelling in teaching literacy}

In implementing storytelling in teaching literacy, there were two challenges that can disturb the effectiveness of teaching program. The challenges had something to do with students' proficiency and length of texts as described in the following subsections.

\section{Students' English proficiency}


The first challenge mainly deals with the students' English proficiency. All students admitted that the lack of language proficiency, such as vocabularies, grammar, and pronunciation, was their obstacle in implementing this teaching program. Consequently, it made students hard in comprehending the text comprehensively and in expressing their opinions, as stated by student below.

I found some difficulties, when teacher asks me to write a sentence that read by her, for example I still confuse with the meaning of those words. (S2) (Interview, translated version)

To facilitate students in understanding difficult words, the teacher should let them to write their stories in Indonesian first (Wright, 2008) before they translated the story into English. After that, teacher also facilitated students to use English-Indonesian or IndonesianEnglish dictionary to make them easier in writing a story and in comprehending a text. It is supported by interview result of student below.

From storytelling, I do not like writing, because I do not know yet the words. Luckily, teacher asks me and my friends to read the story first, after that we understand the story using dictionary so that, I easier in writing a story. (S1) (Interview, translated version)

The students' reading and writing results in the beginning also indicated that the students with better language proficiency were able to have higher score. It was because the students with better language proficiency can comprehend the text better and write their own text properly. Thus, this challenge should be considered by teacher in selecting teaching materials to facilitate all students' English proficiency levels.

\section{The length of the texts}

In addition to students' English proficiency, the length of story is also one of the important things to be considered in implementing storytelling to develop students' literacy skills. As supported by Wright (2008, p. 10), the story should has the right length which is easy to make students comprehend the text. Incorporating to the above statement, students perceived that long stories made them getting bored. Statement of student can be seen below.

I a little bit do not like the story, because some stories are too long, so I am getting bored. For instance, the story of little red riding hood. (S1) (Interview, translated version)
The length of the text also impacted on students' language learning and their reading comprehension. By taking the theory and student's perspective into account, it was suggested for the teacher to select appropriate texts or materials before conducting teaching and learning process in the classroom. Accordingly, it was expected that the students' literacy skill can be developed optimally.

In relation to the aforementioned findings, it can be concluded that storytelling is possible to be implemented in the teaching literacy. After conducted preparatory stage, ten meetings were applied. The meetings consisted of three phases. They were activities before reading the story, activities during reading the story, and activities after reading the story. The ten meeting were divided into seven units. The first until fifth unit explained the data and discussion of storytelling in reading. On the other hand, the sixth and seventh unit focused on writing skill.

In the implementation of unit one until unit seven, it can be obtained that there were several appropriate steps to be implemented by teachers in conducting storytelling. The steps included activities before reading the story, activities during reading the story, and activities after reading the story.

First was related to activities before reading the story. Before telling the stories to the students, brainstorming was the selected activity. The objective of selecting the activity was to find out more about students' existing knowledge and attitude. The activities were begun with showing the picture of the book cover to the students. It was aimed at increasing students' predictive skills. The activity was also conducted based on results of storytelling questionnaire filled by students that students prefer to learn using picture as part of a story. In the beginning, based on the observation sheet in the classroom, students paid their attention and actively participated in answering teacher's questions related to the main story. In this activity, the students were asked to read the title of the story. After introducing title of the story to the students, they were introduced to some unfamiliar vocabularies that often appeared in the story. The activity was applied as a good source of learning new vocabulary and structure. In the implementation, it can be seen that students enjoyed the story because they had known the meaning of difficult words.

The second stage of implementing storytelling was the activity of telling the story. This stage was conducted to encourage students to be active 
and reflective readers. The students were not only expected to be passive readers, but also actively interact with the text. Moreover, in the middle activity, students were expected to comprehend the meaning of the story. The appropriate activity were the use of dramatization to show character's expression or emotion that can attract students' interest in comprehending the story. Besides, the use of several guided questions was appropriate to be implemented. In the process of asking questions, the students also looked at the setting and characters portrayed through language in the book. Thus, it is important for students, especially low proficiency students, to know whether they were still focus on the story or not.

Furthermore, there were activities after reading the story. The activities were divided into three activities. They were giving some exercises related to reading comprehension, performing the story, and creating their own story. First, some exercises were given to the students to know their comprehension of the story. The effective instrument of the evaluation in reading was cloze procedure. Second, students' performance in storytelling was aimed at checking their comprehension and building their self-confidence in doing presentation in a public area. The last, students reflected their knowledge of the story to a piece of writing.

Finally, from five stories implemented in this study, the story of "The Owl Babies" was categorized as the chosen story based on students' interest. It was chosen because students attracted with very short folktales about animals as the main characters. Related to the observation sheet, it was found that the story is appropriate to students' ages and understanding. Besides, based on the result of questionnaire, most of students were preferred to be taught by using picture. On the point of that, the story was selected based on the quality of the book. This is a big book which has proper quality seen from font size and sharpness of pictures inside the book. Moreover, big book helped students to see the pictures clearly. In addition, story book was applied as visual tool to support storytelling activities in teaching and learning process.

\section{CONCLUSION}

Based on data of classroom interview, the data indicated that although there are some restrictions, the incorporation of storytelling to the teaching program had assisted students to increase their reading comprehension ability and to develop their writing skill. On the basis of the data obtained, this research revealed that the teaching program spawned some benefits. Firstly, in the process of implementing storytelling, it was found that students' literacy skill was developed. Secondly, the selection of story and quality of book also gave an impact on arousing their imagination. Moreover, students' vocabulary, reading awareness, and interest also increased. Nevertheless, the attainment of those benefits might be constrained by some challenges found in this teaching program. The challenges had something to do with students' proficiency and length of texts.

Accordingly, it can be concluded that the result of the research confirmed possibility of the teaching program which incorporates storytelling in supporting junior high school students to have good awareness in literacy, both reading and writing. It indicated that storytelling can be applied in EFL junior high school in Indonesia, especially in suburban area, because there are limited facilities that can support students learning. Furthermore, the use of media and teacher as an actor can help students to develop their literacy skill which is highly required in facing globalization era.

Based on the findings, it is suggested to implement storytelling that has been proved to have various positive impacts on students' learning. Nonetheless, this teaching program will be more effective when applied in the regular teaching using classroom action research. It is suggested to obtain deep data of the research and to modify new teaching practice. By considering the suggestion, it is expected that the teaching process can optimize students' reading and writing ability. At last, this program should be tried out in a variety of level of education, especially young learners to check whether it can develop students' literacy skills or not.

\section{REFERENCES}

Al-Mansour, N. S., \& Al-Shorman, R. A. (2011). The effect of teacher's storytelling aloud on the reading comprehension of Saudi elementary stage students. Journal of King Saudi University-Languages and Translation, 23, 69-76.

Cohen, L., Manion, L., \& Morrison, K. (2007). Research methods in education ( $\left.6^{\text {th }} E d\right)$. New York: Routledge.

Crowl, T. K. (1996). Fundamentals of education research. US: Brown and Benchmark Publisher.

Denzin, N. K., \& Lincoln, Y.(2005). Introduction: The discipline and practice of qualitative research. 
In N. K. Denzin \& Y. Lincoln (Eds.), The sage handbook of qualitative research ( $2^{\text {nd }}$ ed.). Thousand Oaks, California: Sage Publication.

Derewianka, B. (1990). Exploring how texts work. Sydney: Primary English Teaching Association.

Emilia, E. (2005). A critical genre-based approach to teaching academic writing in a tertiary EFL context in Indonesia. (Dissertation). Melbourne: Faculty of Education, The University of Melbourne.

Emilia, E. (2010). Teaching writing: Developing critical learners. Bandung: Rizqi Press.

Feez, S. (2002). Heritage and innovation in second language education. In A. M. Johns (Eds.), Genre in the Classroom (pp. 47-68). New Jersey: Lawrence Erlbaum.

Hana, J. (2011). Terapi kecerdasan anak dengan dongeng. Yogyakarta: Berlian Media.

Hancock, J. \& Leaver, C. (2006). Teaching strategies for literacy. Norwood: Australian Literacy Educators' Association Ltd.

Hood, S., Solomon, N., \& Burns, A. (1996). Focus on reading (new edition). Sydney: Macquarie University Press.

McDrury, J., \& Alterio, M. (2003). Learning through storytelling in higher education: Using reflection and experience to improve learning. London: Kogan Page Limited.

McGrath, S. K. (2000). The art of storytelling: A collegiate connection to professional development schools. Journal of Education, 121(1), 184.

Metcalfe, J., Simpson, D., Todd, I., \& Toyn, M. (2013). Thinking through new literacies for primary and early years. Victoria: SAGE Publication.

Nicholas, B. J., Rossiter, M. J., \& Abbott, M. L. (2011). The power of story in the ESL classroom. Canadian Modern Language Review, 67(2), 247-268.

Paul, D. (2003). Teaching English to children in Asia. Quarry Bay: Longman Asia ELT.
Peck, J. (1989). Using storytelling to promote language and literacy development. The Reading Teacher, 43(2), 138-141.

Pinter, A. (2006). Teaching young language learners. Oxford: Oxford University Press.

Rahmawati, I. N. (2014). Teaching speaking through storytelling. (Thesis). School of Postgraduate studies, Universitas Pendidikan Indonesia, Bandung.

Rusdi. (2006). The advantages of storytelling in teaching English. Jurnal Bahasa dan Seni, 7(1), 65-69.

Scott, W. A., \& Ytreberg, L. H. (1990). Teaching English to children. NY: Longman Inc.

Sherman, J. (2008). Storytelling: An encyclopedia of mythology and folklore. New York: M. E. Sharpe, Inc.

Slattery, M., \& Willis, J. (2001). English for primary teachers: A handbook of activities and classroom language. Oxford: Oxford University Press.

Taylor, E. K. (2000). Using folktales. Cambridge: Cambridge University Press.

Tooze, R. (1959). Storytelling. NJ: Prentice Hall.

Wajnryb, R. (2003). Stories: Narratives activities in the language classroom. Cambridge: Cambridge University Press.

Wallace, C. (1992). Reading. Oxford: Oxford University Press.

Walsh, B. A., \& Blewitt, P. (2006). The effect of questioning style during storybook reading on novel vocabulary acquisition of preschoolers. Early Childhood Education Journal, 33(4), 273-278.

Widiastika, W. (2011). The use of big storybook in improving students' vocabulary mastery. (Thesis). Universitas Pendidikan Indonesia, Bandung.

Wright, A. (2008). Storytelling with children. Oxford: Oxford University Press.

Yin, R. K. (1994). Case study research design and methods ( $2^{\text {nd }}$ ed.). Thousand Oaks, California: Sage Publications.

Zaro, J. J., \& Salaberri, S. (1995). Storytelling. Oxford: Macmillan Publishers. 